\title{
Gastrointestinal nematodes of donkeys in and around Alage, South Western Ethiopia
}

\author{
Misgana Naramo ${ }^{1,}$ Yitagele Terefe ${ }^{2}$, Jelalu Kemal ${ }^{2 *}$, Tesfaye Merga ${ }^{3}$, Gelane Haile ${ }^{1}$ and \\ Merga Dhaba ${ }^{1}$ \\ ${ }^{1}$ Animal Health Department, Alage Agricultural Technical and Vocational Education and Train- \\ ing College, P. O. Box 77, Alage, Ethiopia \\ ${ }^{2}$ Haramaya University, College of Veterinary Medicine, P.O.Box 138, Dire Dawa, Ethiopia \\ ${ }^{3}$ The Donkey Sanctuary Alage Partnership Project, P.O. Box 1250, Addis Ababa, Ethiopia \\ *Corresponding author: Haramaya University, College of Veterinary Medicine, P. O. Box 138, \\ Dire Dawa, Ethiopia, Email: jelaluk@gmail.com \\ http://dx.doi.org/10.4314/evj.v20i2.7
}

\begin{abstract}
Gastrointestinal parasites are one of the most common factors that constrain the health and working performance of donkeys. The present study was aimed to estimate the prevalence and identify major risk factors associated with donkey's gastrointestinal nematode infection in and around Alage, South Western Ethiopia. A total of 384 randomly selected donkeys were sampled from 4 peasant associations for coprological examination of gastrointestinal nematode infection. The direct fecal smear, flotation and fecal culture methods were utilized to identify the eggs and larvae of parasites in feces, respectively. The overall prevalence of gastrointestinal nematodes recorded in donkeys examined was $99.5 \%$. The study showed that the prevalence of Parascaris equorum, Oxyuris equi and Strongyle were 53.6\%, 4.9\% and 99.5\%, respectively. Significantly $(\mathrm{P}<0.05)$ higher prevalence was observed for Oxyuris equi and Parascaris equorum in young donkeys than in both adults and old donkeys. The study showed that the prevalence of Strongyle was significantly higher than both Parascaris equorum and Oxyuris equi in all age groups of donkeys. There was also statistically significant difference in prevalence of gastrointestinal nematodes between sex, age, body condition and among peasant associations in different species of the parasites. Identification of third stage larvae of Strongyle species from 40 samples revealed high prevalence of Strongylus vulgaris (100\%) followed by Cythostomes (97.5\%) and Strongylus edentates (70\%). The current study demonstrated that gastrointestinal nematodes are the major health challenges of donkeys in the study area. Therefore strategic dewrming and other nematode control options were recommended to be considered in order to improve the health, productivity and welfare of donkeys in the study area.
\end{abstract}


Keywords: Donkeys; Ethiopia; Gastrointestinal; Nematodes; Prevalence

\section{Introduction}

Ethiopia is one of the developing countries in Africa, which is predominantly an agricultural country with over $85 \%$ of its population engaged in agricultural activity (EARO, 1999). It possess about 5.6 million donkeys, 1.8 million horses and 0.4 million mules (CSA, 2009). Donkeys play an important role in the transportation of farm products, fodder, fuel wood, agricultural in puts and construction and equine power is useful for both a rural and urban transport system, which is cheap and viable. It provides the best alternative in places where the good network is insufficiently developed, other terrains gagged and mountains and cites where narrow streets prevent easy delivery of merchandise (Takele Abayneh et al., 2002).

Parasitic helminthes are one of the most common factors that constrain the health and working performance of donkeys worldwide. Parasites cause various degrees of damage depending on the species and number present, nutritional and the immune status of equines (Tola Mezgebu et al., 2013). In donkeys, infection by internal parasites are responsible for problems including poor body condition, reduced power output, diarrhea, colic, emaciation, impaired growth, poor reproductive performance, short lifespan and predisposition to other infectious diseases (Fikru Regassa et al., 2005; Yoseph Shiferaw et al., 2005; Ayele Gizachew et al., 2006). Internal parasites in donkeys can also cause health damage to the host with clinical signs that include reduced growth rate, abdominal distension, poor body condition, weakness, reduced physical performance and fertility, and death, among others (Brady and Nichols, 2009).

Gastrointestinal parasite has significant negative relation with the health status and working ability in spite of the infection rate. That means the donkey can be infected and still working but generate lower income (Ahmed et $a l .$, 2008). Studies have shown that helminthes in working donkeys are highly prevalent, infection intensities are very high and are the main reasons for early demises of donkeys in the country (Getachew Mulugeta, 1999; Matthee et al., 2000; Fikru Regassa et al., 2005; Getachew Mulugeta et al., 2008a; Getachew Mulugeta et al., 2008b, Trawford and Getachew Mulugeta, 2008; Ayele Gizachew et al., 2006). 
The donkeys have often been described as study animals, yet they are subjected to a variety of diseases and usually remain asymptomatic carriers (Kumar et al., 2009). In Ethiopia including many other African countries, helminthes being an important constraint to growth and productivity (Ayele Gizachew et al., 2006). However, apart from few studies in other parts of Ethiopia, there was no previous information on gastrointestinal (GIT) nematodes of donkeys in and around Alage Agricultural Technical and Vocational Education and Training (ATVET) College. Therefore, the objectives of this study were to estimate the prevalence of GIT nematodes of donkeys and identify the risk factors associated with donkey's GIT nematode infection.

\section{Materials and Methods}

\section{Study area}

The study was conducted at Alage Agricultural Technical and Vocational Education and Training (ATVET) College which is located about $217 \mathrm{~km}$ south east of Addis Ababa and $32 \mathrm{~km}$ west of Bulbula town (Figure 1). ATVET was established in 1981 during the Dergue Regime as an Orphan care center named as "HITSENAT AMBA" since 2002. The area has three distinct seasons, namely main rainy (June to September), short rainy (March to May), and dry (October to February) seasons. Based on ten years data (1996-2005), the mean annual rainfall of the area is $800 \mathrm{~mm}$, with mean minimum and maximum temperatures of 11 and $29^{\circ} \mathrm{C}$, respectively (Shewangizaw Addisu et al., 2013).

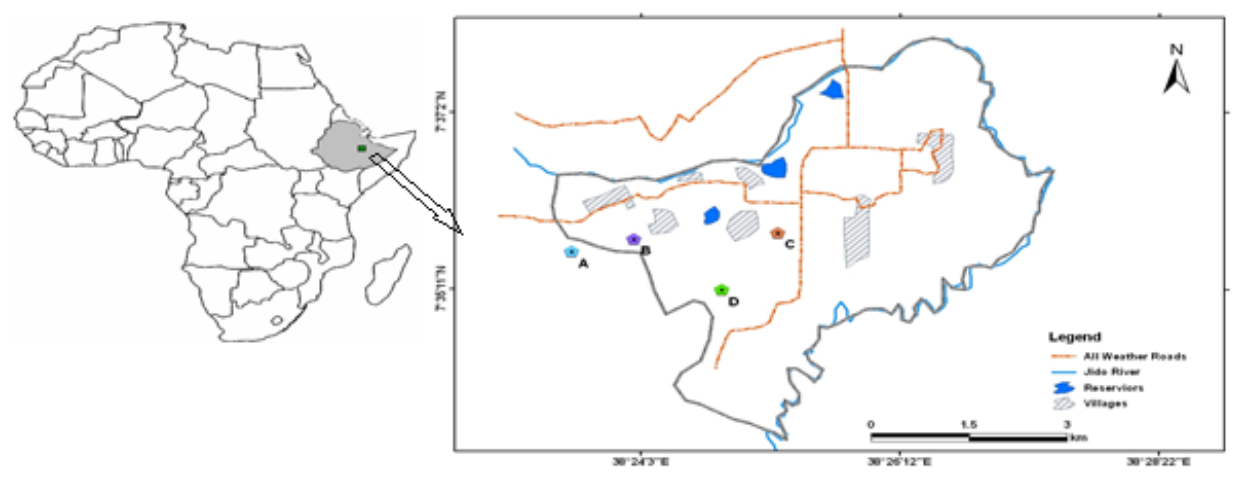

Figure 1: Map of Alage area and location of study sites $(A=$ wheat farm, $B=$ bush land, $\mathrm{C}=$ Acacia woodland, $\mathrm{D}=$ maize farm). 


\section{Study population}

A total of 384 randomly selected donkeys were sampled from 4 peasant associations (Negele wedesha 263, Woje goyate 73, Naka 29 and Alage delbato 19) for coprological examination of GIT nematodes infection in the area. These animals are used by the people to transport of goods and people from one area to another area and sick donkeys from animal health clinic.

\section{Collection and examination of fecal samples}

Fecal samples were collected directly from the rectum of donkeys with universal bottle using sterile disposable gloves. Each sample was labeled with necessary information and transported to Alage ATVET College, animal health parasitology laboratory for examination. Samples were kept in refrigerator at $4^{\circ} \mathrm{C}$ if immediate processing cannot be possible, but it was processed within 24 hours for coproscopy and coproculture to identify the eggs in feces and for identification of Strongyle larvae, respectively. Sodium chloride and magnesium sulfate were used as flotation fluid for this study.

\section{Study design and sample size determination}

A cross sectional study was conducted from October 2013 to July 2014 on 384 randomly selected donkeys. Information about sex, age, body condition and peasant association of the study animals were gathered from the owners. The age of animals was determined by using owners' information and dentition. The donkeys were grouped into three age categories as young when the age is $<2$ years, adult when the age is from 2-10 years and old when the age is beyond 10 years as described by Yoseph Shiferaw et al. (2001). The body condition score (BCS) were subjectively estimated based on the guides published by Svendsen (1997). The age, sex and BCS of each donkey were recorded. Sample size was determined based on an expected prevalence of $50 \%$ for gastrointestinal nematodes as there was no previous report on the prevalence of the parasites in the study area with $95 \%$ confidence level and $5 \%$ absolute precision as the formula given by Thrusfield (2005).

\section{Fecal culture, larvae recovery and identification}

Those samples positive to flotation technique were subjected to fecal culture to see the Strongyle larvae profile in the study area. The samples were cultured 
according to Kaufmann (1996). Approximately 10gm moist and crumbly feces were broken up finely using spatula. Wide mounted plastic jars were filled with the feces, closed with the lid and left at biochemical incubator for 4-7 days stirring the feces each day to prevent the growth of fungi in the culture and L3 (third stage) larvae were recovered using the Baerman technique. A drop of lugol's iodine was added to the sediment to differentiate the larvae which stains the free living nematode yellow, while parasitic $3^{\text {rd }}$ stage larvae remain unstained. The larvae was then identified under low power microscopy (10x objective), based on the shape and number of gut cells, relative size of sheath tail and shape of larvae's tail (Kaufmann, 1996).

\section{Data management and analysis}

The data collected from the study areas were entered into Microsoft Excel spread sheets and the data were coded appropriately and analyzed using SPSS version 20 statistical software's. Chi-square tests was applied to test the statistical association exists among the risk factor such as age, sex and body condition scoring with the presence of the parasite. A statistical significant $\mathrm{P}<0.05$ were used to test the association of the risk factors with the disease prevalence.

\section{Results}

The coprological examination of 384 randomly selected donkeys revealed the presence of 3 different helminthes (Table 1). Strongyle nematodes were detected in 382 (99.5\%) examined donkeys followed by P. equorum (53.6\%). The prevalence of Strongyle was higher than all other detected nematodes. In addition, the study showed that overall prevalence of Strongyle type nematodes was higher in all age groups of donkeys. Poor body condition scored donkeys were significantly infected to nematodes than moderate and ideal body condition scored donkeys (Table 2). Different types of GIT nematodes prevalence were recorded among different peasant associations with higher prevalence in Nagele (Table 3). Similarly, proportion of larvae of different Strongyle parasites recovered from coproculture was determined that showed $100 \%$ prevalence of Strongylus vulgaris followed by Cythostomes with $97.5 \%$ prevalence (Table 4). 
Misgana Naramo et al.,

Table 1: The overall prevalence of gastrointestinal nematodes of donkeys in Alage

\begin{tabular}{lccc}
\hline Parasite species & $\begin{array}{c}\text { No. of donkeys } \\
\text { examined }\end{array}$ & $\begin{array}{c}\text { No. of } \\
\text { samples } \\
\text { positive }\end{array}$ & percent positive \\
\hline Parascaris equorum & 384 & 206 & 53.6 \\
Oxyuris equi & 384 & 19 & 4.9 \\
Strongyle spp & 384 & 382 & 99.5 \\
\hline
\end{tabular}

Table 2: The prevalence of nematodes infection between age, body condition and sex of donkeys

\begin{tabular}{|c|c|c|c|c|c|c|c|c|c|}
\hline \multirow{2}{*}{$\begin{array}{l}\text { Risk } \\
\text { factors }\end{array}$} & \multicolumn{2}{|c|}{$P$. equorum } & \multicolumn{3}{|c|}{ O. equi } & \multicolumn{3}{|c|}{ Strongyle } & \multirow[b]{2}{*}{$\begin{array}{c}\mathrm{X}^{2} \\
\text { P-value }\end{array}$} \\
\hline & $\begin{array}{c}\text { No. of } \\
\text { positive }\end{array}$ & $\%$ & $\mathrm{X}^{2}$ (P-value) & $\begin{array}{c}\text { No. of } \\
\text { positive }\end{array}$ & $\%$ & $\begin{array}{c}\mathrm{X}^{2} \\
\text { (P-value) }\end{array}$ & $\begin{array}{c}\text { No. of } \\
\text { positive }\end{array}$ & $\%{ }^{\circ}$ & \\
\hline \multicolumn{10}{|l|}{ Age group } \\
\hline $\begin{array}{l}\text { Young } \\
\text { (130) }\end{array}$ & 102 & 26.6 & $\begin{array}{c}51.04 \\
(0.000)\end{array}$ & 13 & 3.38 & $\begin{array}{c}10.57 \\
(0.005)\end{array}$ & 129 & 33.6 & $\begin{array}{c}0.65 \\
(0.722)\end{array}$ \\
\hline $\begin{array}{l}\text { Adult } \\
(164)\end{array}$ & 73 & 19 & & 4 & 1 & & 163 & 42.5 & \\
\hline Old (90) & 31 & 8 & & 2 & 0.52 & & 90 & 23.4 & \\
\hline $\begin{array}{l}\text { Total } \\
(384)\end{array}$ & 206 & 53.6 & & 19 & 4.9 & & 382 & 99.5 & \\
\hline \multicolumn{10}{|l|}{$\mathrm{BCS}$} \\
\hline Poor & $87 / 122$ & 22.6 & $\begin{array}{c}34.47 \\
(0.000)\end{array}$ & $12 / 122$ & 3.1 & $\begin{array}{c}9.05 \\
(0.010)\end{array}$ & $121 / 122$ & 31.5 & $\begin{array}{c}1.69 \\
(0.429)\end{array}$ \\
\hline Moderate & $91 / 171$ & 23.7 & & $5 / 171$ & 1.3 & & $171 / 171$ & 44.5 & \\
\hline Ideal & $28 / 91$ & 7.3 & & $2 / 91$ & 0.5 & & $90 / 91$ & 23.5 & \\
\hline $\begin{array}{l}\text { Total } \\
(384)\end{array}$ & & 53.6 & & & 4.9 & & & 99.5 & \\
\hline \multicolumn{10}{|l|}{ Sex } \\
\hline $\begin{array}{l}\text { Male } \\
(169)\end{array}$ & 90 & 23.4 & $\begin{array}{c}0.19 \\
(0.892)\end{array}$ & 7 & 1.8 & $\begin{array}{c}.417 \\
(0.519)\end{array}$ & 169 & 44 & $\begin{array}{c}1.58 \\
(0.209)\end{array}$ \\
\hline $\begin{array}{l}\text { Female } \\
(215)\end{array}$ & 116 & 30.2 & & 12 & 3.1 & & 213 & 55.5 & \\
\hline $\begin{array}{l}\text { Total } \\
(384)\end{array}$ & 206 & 53.6 & & 19 & 4.9 & & 382 & 99.5 & \\
\hline
\end{tabular}


Table 3: The prevalence of GIT nematodes in different peasant association of the study sites

\begin{tabular}{|c|c|c|c|c|c|c|c|c|c|}
\hline \multirow{2}{*}{$\begin{array}{l}\text { Peasant } \\
\text { association }\end{array}$} & \multicolumn{3}{|c|}{$P$. equorum } & \multicolumn{2}{|l|}{ O. equi } & \multicolumn{3}{|c|}{ Strongyle } & \multirow[b]{2}{*}{$\begin{array}{c}\mathrm{X}^{2} \\
\text { (P-value) }\end{array}$} \\
\hline & $\begin{array}{c}\text { No. } \\
\text { positive }\end{array}$ & $\%$ & $\begin{array}{c}\mathrm{X}^{2} \\
\text { (P-value) }\end{array}$ & $\begin{array}{c}\text { No } \\
\text { positive }\end{array}$ & $\%$ & $\begin{array}{c}\mathrm{X}^{2} \\
\text { (P-value) }\end{array}$ & $\begin{array}{c}\text { No } \\
\text { positive }\end{array}$ & $\%$ & \\
\hline $\begin{array}{l}\text { Nagele } \\
(263)\end{array}$ & 149 & 38.8 & $\begin{array}{c}4.31 \\
(0.229)\end{array}$ & 14 & 3.6 & $\begin{array}{c}1.25 \\
(0.741)\end{array}$ & 261 & 68 & $\begin{array}{c}0.925 \\
(0.819)\end{array}$ \\
\hline $\begin{array}{l}\text { Wojegoyato } \\
(73)\end{array}$ & 34 & 8.8 & & 4 & 1 & & 73 & 19 & \\
\hline Naka (29) & 12 & 3.1 & & 1 & 0.3 & & 29 & 7.5 & \\
\hline $\begin{array}{l}\text { Algedelbato } \\
(19)\end{array}$ & 11 & 2.9 & & 0 & 0 & & 19 & 5 & \\
\hline Total (384) & 206 & 53.6 & & 19 & 4.9 & & 382 & 99.5 & \\
\hline
\end{tabular}

Table 4: Relative percentage of larvae of different Strongyle parasites recovered from coproculture

\begin{tabular}{lccc}
\hline $\begin{array}{l}\text { Types of } \\
\text { Strongyle larvae }\end{array}$ & $\begin{array}{c}\text { No of donkeys } \\
\text { examined }\end{array}$ & $\begin{array}{c}\text { Number } \\
\text { positive }\end{array}$ & Prevalence \\
\hline $\begin{array}{l}\text { Strongylus vulgaris } \\
\text { Strongylus }\end{array}$ & 40 & 40 & 100 \\
edentatus & 40 & 28 & 70 \\
Cythostomes & 40 & 39 & 97.5 \\
\hline
\end{tabular}

\section{Discussion}

Based on faecal examinations, the overall prevalence of GIT nematodes recorded in the present study was $99.5 \%$ (Table 1). It suggested that donkey's gastrointestinal nematodes are the major helminthes in and around Alage ATVET College. The highest prevalence with $99.5 \%$ of the donkeys showing evidence of infection was Strongyle spp followed by Parascaris equorum (53.6\%). The prevalence of Strongyle spp. was in comparable with the results of Ayele Gizachew et al. (2006), Yoseph Shiferaw et al. (2001), Mulate (2005) and Fikru Regassa et al. (2005) who have reported 100\%, 100\% 100\% and $98.2 \%$ in donkeys of Dugda bora district, Wonchi, high lands of Wollo province, in North and South Wollo and western highlands of Oromia, respectively.

Another study conducted by Getachew Mulugeta et al. (2006) found that 99\% prevalence of Strongyle in Ethiopia which is also in line with the present study. All groups of donkeys had no statistically significant association with 
the prevalence of Strongyle. A similar finding was reported by Ayele Gizachew et al. (2006). This might be attributed to an augmentation of land cultivation which restricts donkeys on small communal grazing land allowing the animals for continuous larvae exposure to infected pasture.

The prevalence of donkeys passing Parascaris eggs by faeces was 53.6\%, which is comparatively in agreement with Getachew Mulugeta et al. (2006), Ayele Gizachew et al. (2006) and Mulate (2005) who have reported 51\%, 50\% and $48.8 \%$ in Ethiopia, in Dugda Bora district and in south and north Wollo provinces, respectively. The present finding disagree with Yoseph Shiferaw et al. (2001) and Fikru Regassa et al. (2005) who have reported $15.7 \%$ and $17.1 \%$ in highland of Wollo provinces and in western highlands of Oromia, respectively. These differences might be due to the ecological and climatic difference among localities. Oxyuris equi with prevalence rate of $4.9 \%$ was very low compared with the work of Yoseph Shiferaw et al. (2001) who reported $32.4 \%$ and relatively high compared with $3 \%$ prevalence of Ayele Gizachew et al. (2006). The low prevalence in this study might be the effect of relative higher temperature in the present study area which affects the highly susceptible Oxyuris equi eggs (Ayele Gizachew et al., 2006).

Identification of infective larvae of helminths showed that Strongylus vulgaris and Cyathostomes were the major larvae encountered with highest percentage of $100 \%$ and $97.5 \%$ respectively. The prevalence of Strongylus edentatus were $70 \%$. This finding agrees with observations of Ayele Gizachew et al. (2006) and Yoseph Shiferaw et al. (2001) who have reported 100\%. This supports the observations of high overall prevalence results recoded from fecal examinations of the current study.

This study confirmed that there is a significant difference in the prevalence of the parasite among the different body condition scores and it is shown helminthes parasites are more prevalent in animals with poor body condition than well-conditioned animals which are in agreement with the results of Ayele Gizachew et al. (2006) which implies that the body condition score is a good indicator of parasitic burden, which can be used by farmers to identify donkeys with immediate requirement of anthelmintic remedies. The present study might suggest that young age donkeys have less immunity against helminthes than both adult and old age donkeys. 
The highest mean Oxyuris egg and Parascaris egg was observed in young age group than adult and old donkeys. This finding is in agreement with previous studies of Fikru Regassa et al. (2005) and Ayele Gizachew et al. (2006). This study might also suggest that there was significantly difference prevalence of helminthes between male and female donkeys in the study area. This finding agrees with observations of Bewketu Takele and Endalkachew Nibret (2013), Ayele Gizachew et al. (2006) and Yoseph Shiferaw et al. (2001). This is due to female donkeys might be have low immunity than male because females were highly prone to disease during parturition, pregnancy, etc. This finding was observed statically differences between peasant associations with no statically differences Strongyle infection but the number of population was increased from site to sites. This finding agrees with observations of Mulate (2005).

\section{Conclusion}

The present study suggested that donkey's gastrointestinal nematodes are the major helminthes in and around Alage ATVET College with an overall prevalence of $99.5 \%(53.6 \%, 4.9 \%$ and $99.5 \%$ for $P$. equerem, O. equi and Strongyle respectively). Age and body condition are the most prominent risk factors associated with gastrointestinal nematode infection. In addition, weak status of animal health services and lack of proper management especially in the study area, mixed crop-livestock farming and cultivation of most land were observed to be contributing factors. The owners of the study area give low priority to donkeys. They give the first line to draught animals to graze highly pastured grass but working donkeys are allowed to graze behind on overstocked areas which lead them to graze close to the ground and on fecal materials, resulting in the uptake of higher numbers of infective larvae. As a result, owners should be educated about proper management of donkeys to reduce the worm burden and minimize pasture contamination with larvae.

\section{Acknowledgements}

The authors would like to thank Dr. Chala Fayara for his thorough and unreserved comments. Donkey sanctuary project partnership of Alage receives especial thank for the financial and material support. We also would like to thank the owners of donkeys and animal health assistants working in different veterinary clinics around Alage ATVET College for their cooperation and quick reply to all questions. 


\section{References}

Abayneh, T., Gebreab, F., Zekarias, B. and Tadesse, G., 2002. The potential role of donkeys in land tillage in central Ethiopia. Bull. Anim. Hlth. Prod. Afr., 50, 172 178.

Addisu, S., Tegegne, F. and Mekuriaw, Z., 2013. Effect of different levels of dietary bole (Lake Soil) inclusion on feed intake, milk yield and composition of Holstein Friesian cows. Inter. J. Agri. Biosci., 2(6), 377-382.

Ahmed, M. I., Tijjani, A. N. and Mustapha, A. R., 2008. Survey for common diseases and management practices of donkeys (Equus asinus) in Bruno State, Nigeria. Nigerian Vet. J., 29(3), 1-5.

Bewketu, T. and Endalkachew, N., 2013. Prevalence of gastrointestinal helminthes of donkeys and mules in and around Bahir Dar, Ethiopia. Ethiop. Vet. J., 17(1), 1330.

Brady, H.A. and Nichols, W.T., 2009. Drug resistance in equine parasites: An emerging global problem. J. Equine Vet. Sci., 29(5), 285-295.

CSA, 2009. Central Statistical Authority of Ethiopia. Annual live stock samples survey volume I Statistical Bulletin 132, Addis Ababa, Ethiopia.

Dawit, S. and Taye., 2009. The epidemiology and public health importance of bovine TB in Alage Dairy farm in the southern Ethiopia.

EARO, 1999. National animal health research programmed strategy document, Ethiopia Agricultural Research Organization (EARO), Addis Ababa, Ethiopia.

Getachew, M., 1999. Epidemiological study on the health and welfare of Ethiopian donkeys, with particular reference to parasitic diseases, (Unpublished MVM Thesis University of Glasgow Scotland, UK).

Getachew, M., Feseha, G., Trawford, A. and Reid, S. W. J., 2008b. A survey of seasonal patterns in Strongyle faecal worm egg counts of working equids of the central midlands and lowlands, Ethiopia. Trop. Anim. Health Prod., 40, 637-642.

Getachew, M., Innocent, G., Trawford, A., Feseha, G., Reid, S. W. J. and Love, S., 2006. A sero-epidemiological study of equine tapeworm, Anoplocephala perfoliata in donkeys, Ethiopia. In: Bakkoury, M. and Dakkak A., (eds), In Proceedings of the $9^{\text {th }}$ Congress of the World Equine Veterinary Association (WEVA), Marrakech, Morocco, 263-264.

Getachew, M. A., Innocent, T. G., Trawford, F. A., Feseha, G., Reid, S. W. J. and Love, S., 2008a. Equine parascariosis under the tropical weather conditions of Ethiopia: a coprological and postmortem study, Vet. Rec., 162, 177-180. 
Gizachew, A., Gebreab, F., Endebu, B., and Joe, A., 2006. Prevalence of gastrointestinal parasites of donkeys in Dugda Bora District, Ethiopia. Livest. Res. Rural Dev., 18 (10), 1-11.

Kaufmann, J., 1996. Parasitic Infections of Domestic Animals, a Diagnostic Manual. Birhavsen verleg, Germany, Pp: 224-227.

Kumar, S., Kumar, R., and Sugimotom, C., 2009. A perspective on Theileria equi infections in donkeys. Jpn. J. Vet. Res., 56(4), 171-80.

Matthee, S., Krecek, R. C. and Milne, S. A., 2000. Prevalence and biodiversity of helminth parasites in donkeys from South African. J. Parasitol,, 86, 756-762.

Mezgebu, T., Tafess, K., Tamiru, F., 2013. Prevalence of Gastrointestinal Parasites of Horses and Donkeys in and around Gondar Town, Ethiopia. OJVM., 3, 267-272.

Mulate, B., 2005. Preliminary study on helminthosis of equines in south and north Wollo Zones. Ethiop. Vet. J., 9, 25-37.

Regassa, F., Reta, D. and Mideksa, B., 2005. Prevalence of equines gastrointestinal parasites in western highlands of Oromia, Ethiopia. Bull. Anim. Hlth. Prod. Afr., 53, 161-166.

Shiferaw, Y., Smith, D. G., Mengistu, A., Teklu, F., Firwe T. and Betere, Y., 2005. Seasonal variation in the parasite burden and body condition of working donkeys in east Shewa and West shew Regions of Ethiopia. Trop. Anim. Health Prod., 37, $35-45$.

Shiferaw, Y., Gebreab, F. and Wossene, A., 2001. Survey on helminthosis of equines in Wonchi, Ethiopia. Ethiop. Vet. J., 5, 49- 67.

Svendsen, E. D., 1997. Parasites Abroad, In: E. D. 7 Ed., the Professional Handbook of the Donkey, Whittet Books Limited, London, pp. 227-238.

Thrusfield, M., 2005. Sampling In: Veterinary epidemiology, $3^{\text {rd }}$ edn, London, Black well science Ltd. Oxford, UK, pp. 182-198.

Trawford, A. and Getachew, M., 2008. Parasites. In: Duncan, J. and Hadrill D., (eds). The Professional Handbook of the Donkey ( $4^{\text {th }}$ ed). Whittet Books Limited. South House, Yatesbury, Wiltshire, UK, pp. 82-101. 